\title{
Commentary on comparison of MODIS snow cover and albedo products with ground observations over the mountainous terrain of Turkey
}

\author{
A. Ü. Şorman ${ }^{1}$, Z. Akyürek ${ }^{1}$, A. Şensoy ${ }^{2}$, A. A. Şorman ${ }^{2}$, and A. E. Tekeli ${ }^{3}$ \\ ${ }^{1}$ Department of Civil Engineering, Middle East Technical University, Ankara, Turkey \\ ${ }^{2}$ Department of Civil Engineering, Anadolu University, Eskisehir, Turkey \\ ${ }^{3}$ Remote Sensing Division, Turkish State Meteorological Service, Ankara, Turkey
}

Received: 1 November 2006 - Published in Hydrol. Earth Syst. Sci. Discuss.: 11 December 2006

Revised: 27 March 2007 - Accepted: 1 May 2007 - Published: 22 May 2007

\begin{abstract}
The MODerate-resolution Imaging Spectroradiometer (MODIS) snow cover product was evaluated by Parajka and Blösch (2006) over the territory of Austria. The spatial and temporal variability of the MODIS snow product classes are analyzed, the accuracy of the MODIS snow product against numerous in situ snow depth data are examined and the main factors that may influence the MODIS classification accuracy are identified in their studies. The authors of this paper would like to provide more discussion to the scientific community on the "Validation of MODIS snow cover images" when similar methodology is applied to mountainous regions covered with abundant snow but with limited number of ground survey and automated stations.

Daily snow cover maps obtained from MODIS images are compared with ground observations in mountainous terrain of Turkey for the winter season of 2002-2003 and 20032004 during the accumulation and ablation periods of snow. Snow depth and density values are recorded to determine snow water equivalent (SWE) values at 19 points in and around the study area in Turkey. Comparison of snow maps with in situ data show good agreement with overall accuracies in between 62 to 82 percent considering a 2-day shift during cloudy days. Studies show that the snow cover extent can be used for forecasting of runoff hydrographs resulting mostly from snowmelt for a mountainous basin in Turkey.

MODIS-Terra snow albedo products are also compared with ground based measurements over the ablation stage of 2004 using the automated weather operating stations (AWOS) records at fixed locations as well as from the temporally assessed measuring sites during the passage of the satellite. Temporarily assessed 20 ground measurement sites are randomly distributed around one of the AWOS stations
\end{abstract}

Correspondence to: A. Ü. Şorman

(sorman@metu.edu.tr) and both MODIS and ground data were aggregated in GIS for analysis. Reduction in albedo is noticed as snow depth decreased and SWE values increased.

\section{Introduction}

The analysis of the Moderate Resolution Imaging Spectroradiometer (MODIS) snow cover maps over the territory of Austria was performed in three steps by Parajka and Blösch (2006).The frequencies of MODIS classes were evaluated, the in situ measurements of snow depth were used to statistically evaluate the accuracy of the MODIS snow images, the potential error sources were analyzed. There have been evaluations of this product in the previous studies, however it is a useful study covering a new region and for a longer period than some of the previous evaluations Hall et al. (2002), Hall et al. (2001), Bitner et al. (2002), Klein and Barnett (2003), Maurer et al. (2003), Zhou et al. (2005), Simic et al. (2004). The length of daily records covering the period from February 2000 to December 2005 over Austria provides the authors to draw more conclusive comments and discussions than the earlier ones on the same subject. The authors of this paper would like to provide more clarification on the "Validation of MODIS snow cover images" when similar methodology is applied to data sparse mountainous regions covered with abundant snow but with limited number of ground survey and automated stations.

Headwaters of the Euphrates River basin is located on the mountainous regions of the eastern part of Turkey where snow cover is abundant. The basin is largely fed from snow precipitation whereby nearly two-thirds occur in winter and may remain in the form of snow for half of the year. The concentration of discharge mainly from snowmelt during spring

Published by Copernicus Publications on behalf of the European Geosciences Union. 


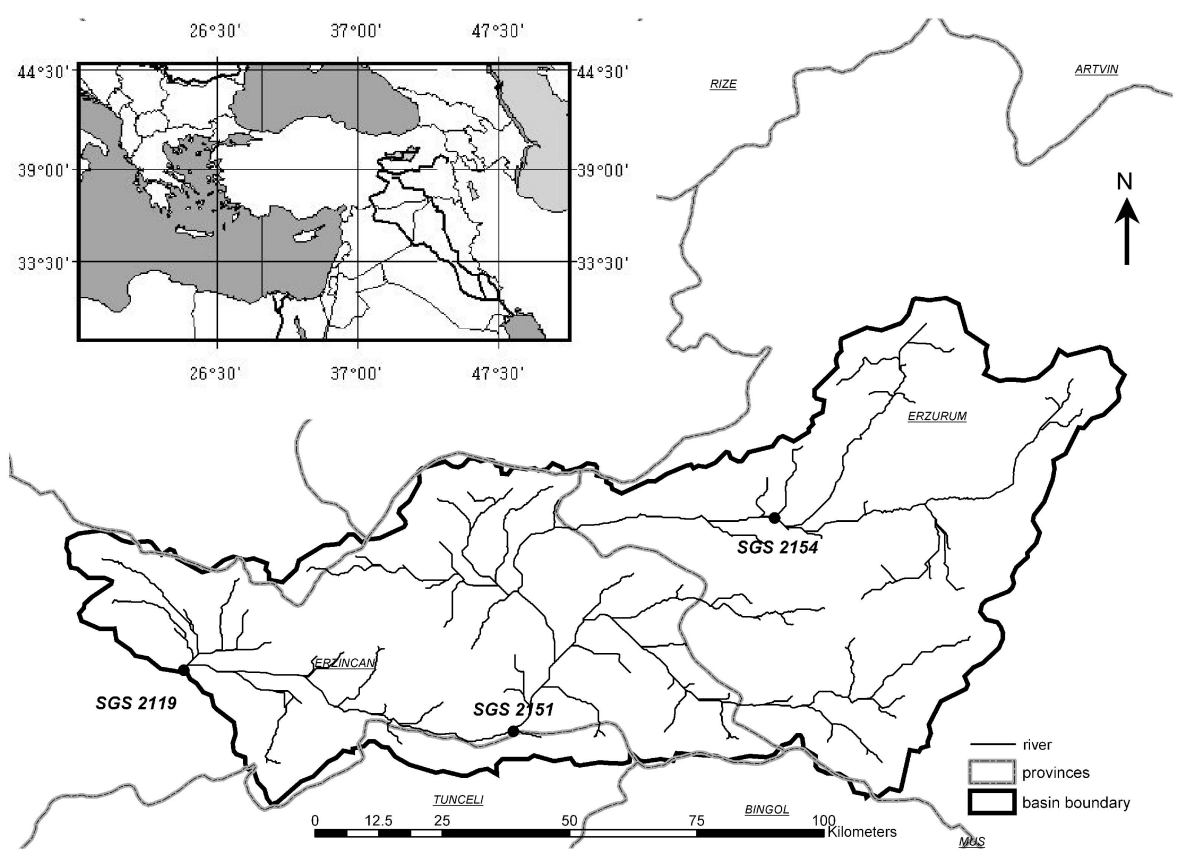

Fig. 1. Location of Karasu Basin (upper Euphrates River) in Turkey and stream gauging stations (SGS) in the basin.

and early summer months causes not only extensive flooding, inundating large areas, but also the loss of much needed water required for irrigation and power generation purposes during the summer season. Accordingly, modeling of snowcovered area in the mountainous regions of eastern Turkey, as being one of the major headwaters of Euphrates-Tigris basin, has significant importance in forecasting snowmelt discharge especially for energy production, flood control, irrigation and reservoir operation optimization. There is not yet a well established operational snow monitoring system in the region. Therefore, comparison of satellite derived snow maps and snow course ground measurements is vital for the improvement of the existing mapping algorithms.

Distributed snow models may require the following spatially distributed parameters: DEM derived terrain parameters, snow-covered area, grain size, albedo, snow water equivalent, snow temperature profile and meteorological conditions, including radiation. The applicability of Earth Observation (EO) satellite images and products in hydrological modeling for mountainous terrain, where scarcity of the ground data is obvious, is the main problem for hydrological earth science. The paper presents here the critical issues for the comparison of the parameters that optical remote sensing can deliver in terms of snow recognition with snow survey. The authors of this paper would like to enlarge the topic presented by Parajka and Blösch (2006) by referring to the studies carried on the consistency of satellite snow products of both snow covered area and albedo in comparison with ground truth data in Turkey.The paper presents here the critical issues for the comparison of the products that optical remote sensing can deliver (snow-covered area and albedo as MODIS products) with snow course and lately established automated weather operating stations (AWOS). The snow covered area validation was performed in published papers of the discussion paper authors (Tekeli et al., 2005) using MODIS images during the accumulation and ablation periods of 2002-2003 water year as well as during the winter period in 2003-2004. Over the ablation period of 2004, daily snow albedo values retrieved from MODIS Terra were compared with ground-based albedo measurements (Tekeli et al., 2006). The studies on the validation of MODIS snow cover images are explained refereeing to the work carried out by Parajka and Blösch (2006) essentially concentrating on the cloud covering frequency problem, comparison of point data with a satellite product and hydrological model application using MODIS snow covered area product.

\section{Description of study area}

The study area is the Karasu Basin located in the eastern part of Turkey (Fig. 1) which is one of the major headwaters of the Euphrates River. At present, the Euphrates and Tigris are the two largest trans-boundary rivers in Western Asia where Turkey, Syria, Iran, Iraq and Saudi Arabia are the riparian countries. The Euphrates and Tigris basins are largely fed from snow precipitation over the uplands of northern and eastern Turkey whereby nearly two-thirds occur in winter and may remain in the form of snow for half of the year. The Upper Euphrates river basin (Karasu basin) is a rugged 

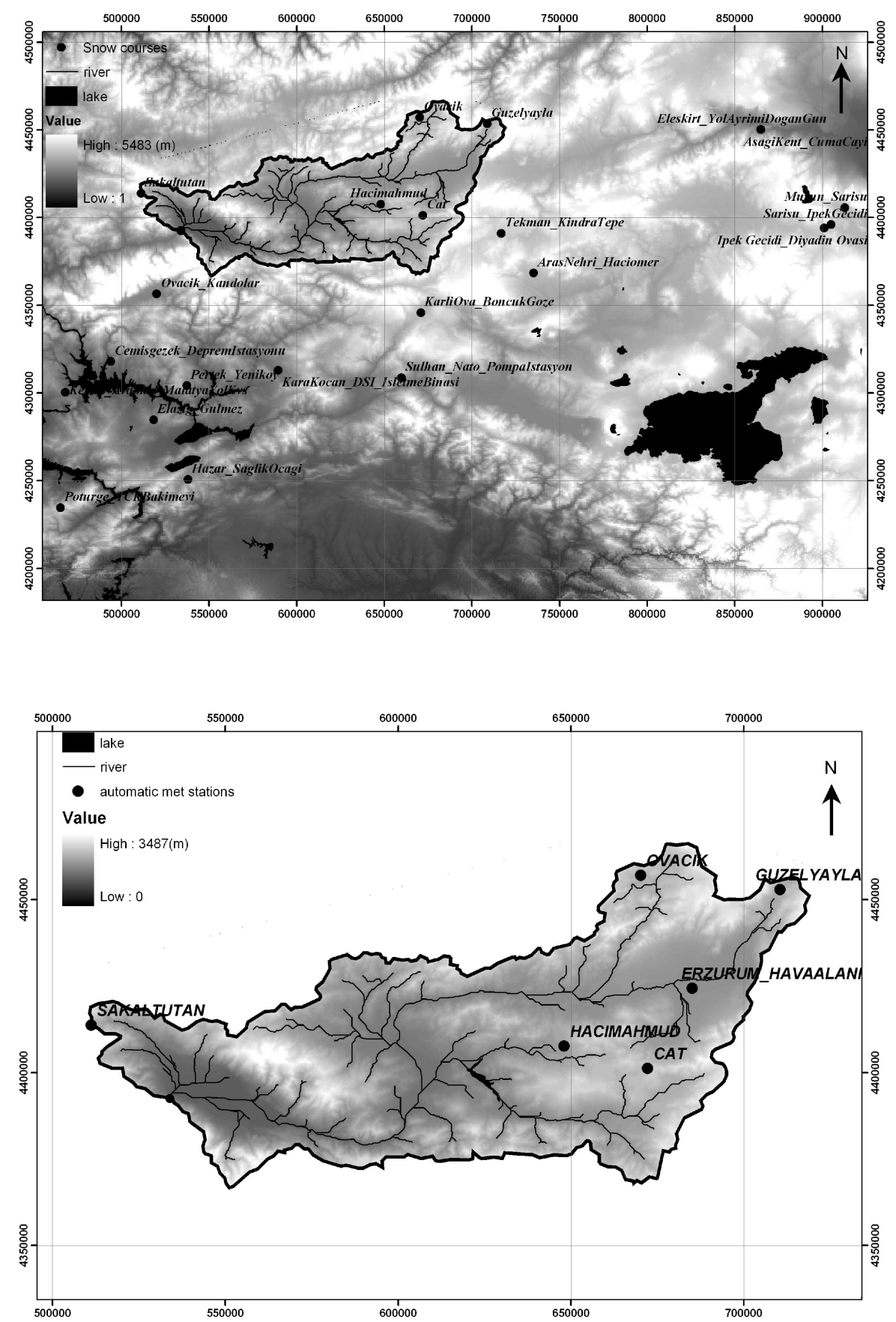

Fig. 2. (a)Snow courses on the topograpic map of Karasu Basin and the surrounding area, (b) AWOS locations on the DEM of Karasu Basin.

mountainous region much affected by snow. The basin boundaries are within the longitudes $38^{\circ} 58^{\prime} / \mathrm{E}$ to $41^{\circ} 39^{\prime} / \mathrm{E}$ and latitudes $39^{\circ} 23^{\prime} / \mathrm{N}$ to $40^{\circ} 25^{\prime} / \mathrm{N}$. Land cover in Karasu basin is mainly pasture, shrub, bare land and cultivated area. Its outlet is controlled by the stream gauging station EIE 2119 under the supervision of General Directorate of Electrical Power Resources Survey and Development Adminis- tration (EIE) in Turkey. Length of the main river in the basin is around $300 \mathrm{~km}$. When the long-term runoff hydrographs at the EIE 2119 stream gauging station is analyzed, it can be seen that around $69 \%$ of total annual volume contribute to the flow during the snowmelt period of mid March through mid July. The basin has a drainage area of $10216 \mathrm{~km}^{2}$ with elevations ranging from $1125 \mathrm{~m}$ to $3487 \mathrm{~m}$. The topographic 


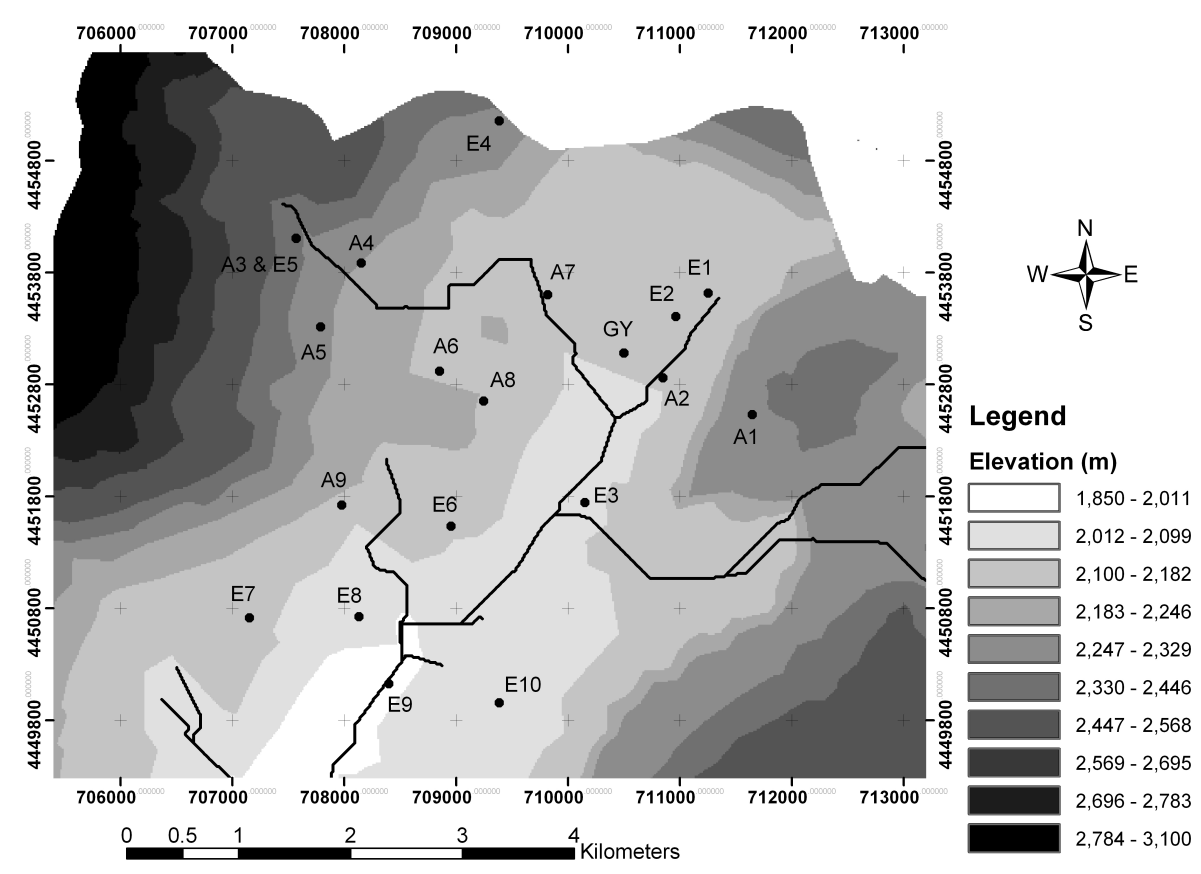

Fig. 3. Locations of snow and albedo measurements during 22-25 March 2004.

Bad figure quality. Please submit a new figure.

map of the basin (DEM) and the surrounding area is shown in Fig. 2a. The snow course measurements conducted by the Government Agencies are also presented in Fig. 2a. The locations of the AWOS stations established by the project team (authors) in the basin is shown in Fig. 2b. All of the data collected during the project period were used to validate spatial and temporal variability of MODIS snow products.

\section{Ground data measurement}

\subsection{Snow depth measurements}

The locations of snow measuring courses (19) and automated meteorological stations (6) are shown in Figs. 2a-b.

Consistency analysis for the winter period was performed for the winter period of 2003-2004 for consecutive four days between 22-25 March 2004 during which 20 random ground point measurements were collected around Güzelyayla AWOS as shown in Fig. 3. The main focus was to assess the spatial variation of MODIS snow cover products and compare them with the ground observations.

\subsection{Albedo measurements}

Two albedometers installed at Güzelyayla and Ovacık AWOS provide the main albedo data set used in Tekeli et al. (2006) (Fig. 2b). A CM3 set with the same spectral characteristics at the two AWOS was used for measuring snow albedo at 20 locations randomly distributed within a $7 \mathrm{~km}$ by $5 \mathrm{~km}$ area around Güzelyayla (GY) AWOS (Fig. 3). The entire system was composed of a snowmobile, a portable albedometer, a data logger and a power supply. Site visits were performed during 22-25 March 2004 when most of the area was covered by snow with some small snow free patches.

\section{MODIS data and methodology}

The processed MODIS products were distributed by the DAAC at the National Snow and Ice Data Center (NSIDC). Two tile images were obtained (h21v04 and h21v05) in order to represent the region. They were reprojected to WGS84 zone 37 UTM with a cell size of $500 \mathrm{~m}$ each. The approach similar to the discussion paper is followed to obtain SCA maps, high snow reflectance in the visible bands and low reflectance in the shortwave infrared wavelength as proposed by Hall et al. (2001); Salomonson and Appel (2004). The algorithm is fully automated based on Normalized Difference Snow Index (NDSI) and a set of thresholds (Hall et al., 2002). For reduction of NDSI in forested areas, Normalized Difference Vegetation Index (NDVI) in conjunction with NDSI is used. The snow mapping accuracy is improved and spurious snow is eliminated by utilizing a thermal mask. MODIS infrared bands 31 and 32 are used with a split window technique (Key et al., 1997) to estimate if ground temperature of a pixel is greater than $277^{\circ} \mathrm{K}$, so as to map the pixel as no snow (Hall et al., 2002). A total of 84 daily MODIS satellite images were analyzed during the period of December 2002 to April 2003. 
Table 1. Summary of analysis for MODIS images performed in winter 2002-2003 (December-March) at snow courses and automated stations with respect to elevation zones.

\begin{tabular}{lcccc}
\hline Elevation zones & $\begin{array}{c}\text { Number of } \\
\text { observations }\end{array}$ & $\begin{array}{c}\text { Matched with } \\
\text { MODIS }\end{array}$ & $\begin{array}{c}\text { Undetermined } \\
\text { due to cloud }\end{array}$ & $\begin{array}{c}\text { Matched } \\
(\%)\end{array}$ \\
\hline A $(1125-1500 \mathrm{~m})$ & 16 & 11 & 5 & 68.75 \\
B $(1500-1900 \mathrm{~m})$ & 15 & 13 & 2 & 86.67 \\
C $(1900-2300 \mathrm{~m})$ & & 11 & 6 & 64.71 \\
Snow courses & 17 & 73 & 155 & 32.02 \\
Automated stations & 228 & & & \\
D (2300-2900 m) & 57 & 22 & 35 & 38.59 \\
Automated station & 57 & & & \\
\hline
\end{tabular}

Table 2. Summary of analyses for MODIS images in winter 2002-2003.

\begin{tabular}{cccc}
\hline \multicolumn{4}{l}{ MODIS classification (on the date ground observation) } \\
\hline Ground truth data & Snow & Undetermined due to cloud & Matched (\%) \\
snow & 61 & 37 & 62.24 \\
\hline MODIS classification (one day shift from the date of ground observation) \\
\hline Ground truth data & Snow & Undetermined due to cloud & Matched (\%) \\
snow & 70 & 28 & 71.43 \\
\hline MODIS classification (two day shift from the date of ground observation) \\
\hline Ground truth data & Snow & Undetermined due to cloud & Matched (\%) \\
snow & 80 & 18 & 81.63 \\
\hline
\end{tabular}

MODIS daily snow albedo values were computed based on the prototype algorithm given in Klein et al. (2000) and Klein and Stroeve (2002). The prototype is similar to the algorithm used to produce the current beta test product (Klein, 2003). Comparisons of MODIS daily snow albedo with ground observations were performed based on the data gathered from AWOS and the 20 random albedometer observations. Since the snow albedo is dependent upon various factors, such as snow density, grain size and surface impurities of the snowpack, which itself is a heterogeneous medium, point values were compared with MODIS pixel values rather than performing any kind of averaging methodology with neighboring pixels. MODIS snow albedo measurements are broadband albedo values, where the conversion was performed by applying the method of Liang et al. (1999). The percentage differences between the daily MODIS data and the ground observations were computed for each of the twohourly intervals during which the AWOSs log the data. Since such two-hourly data were not available for the 20 in situ field observations, only a single difference between the site albedo and that of MODIS is performed.

\section{Analysis}

The observations for the two data sets namely winter 20022003 and March 2004 from the ground data were compared with MODIS pixels ( 500 by $500 \mathrm{~m}$ each) falling within a radius of $1500 \mathrm{~m}$ of the individual site location. If $50 \%$ or more of all cloud free cells within this radius were present then they were classified as snow covered pixels by MODIS satellite. A snow depth of $25.4 \mathrm{~mm}$ proposed by Simic et al. (2004) was selected as a threshold value to indicate snow presence on the ground surface. On the other hand, Maurer et al. (2003) proposed this value to be greater than $10 \mathrm{~mm}$ and this is accepted by Parajka and Blösch (2006).

Cloud cover frequency for the winter months in Turkey was noticed to be high during data analysis; therefore the images acquired a few days ( 1 or 2 days) before and after the ground measured data were also processed if the cell was noticed as cloud obscured in the same date of ground truth.

The results of Parajka and Blöschl (2006) indicated that, on average, clouds obscured $63 \%$ of Austria that may significantly restrict the applicability of the MODIS snow cover images in hydrologic modeling. This high cloud covering frequency was also observed in the study of Tekeli et al. (2005). This is the main reason of the reduced matched percentages. 
Table 3. Analyses performed for winter 2003-2004 March (ablation period).

\begin{tabular}{lcccc}
\hline Location & 22 March 2004 & 23 March 2004 & 24 March 2004 & 25 March 2004 \\
\hline A1 & $\mathrm{S}$ & $\mathrm{S}$ & $\mathrm{C}$ & $\mathrm{S}$ \\
A2 & $\mathrm{S}$ & $\mathrm{S}$ & $\mathrm{C}$ & $\mathrm{S}$ \\
A3 & $\mathrm{S}$ & $\mathrm{S}$ & $\mathrm{S}$ & $\mathrm{S}$ \\
A4 & $\mathrm{S}$ & $\mathrm{S}$ & $\mathrm{S}$ & $\mathrm{S}$ \\
A5 & $\mathrm{S}$ & $\mathrm{S}$ & $\mathrm{C}$ & $\mathrm{S}$ \\
A6 & $\mathrm{S}$ & $\mathrm{S}$ & $\mathrm{C}$ & $\mathrm{S}$ \\
A7 & $\mathrm{S}$ & $\mathrm{S}$ & $\mathrm{C}$ & $\mathrm{S}$ \\
A8 & $\mathrm{S}$ & $\mathrm{S}$ & $\mathrm{C}$ & $\mathrm{S}$ \\
A9 & $\mathrm{S}$ & $\mathrm{S}$ & $\mathrm{C}$ & $\mathrm{S}$ \\
E1 & $\mathrm{S}$ & $\mathrm{S}$ & $\mathrm{C}$ & $\mathrm{S}$ \\
E2 & $\mathrm{S}$ & $\mathrm{S}$ & $\mathrm{C}$ & $\mathrm{S}$ \\
E3 & $\mathrm{S}$ & $\mathrm{S}$ & $\mathrm{C}$ & $\mathrm{S}$ \\
E4 & $\mathrm{S}$ & $\mathrm{S}$ & $\mathrm{C}$ & $\mathrm{S}$ \\
E5 & $\mathrm{S}$ & $\mathrm{S}$ & $\mathrm{S}$ & $\mathrm{S}$ \\
E6 & $\mathrm{S}$ & $\mathrm{S}$ & $\mathrm{C}$ & $\mathrm{S}$ \\
E7 & $\mathrm{C}$ & $\mathrm{S}$ & $\mathrm{C}$ & $\mathrm{S}$ \\
E8 & $\mathrm{C}$ & $\mathrm{S}$ & $\mathrm{C}$ & $\mathrm{S}$ \\
E9 & $\mathrm{S}$ & $\mathrm{S}$ & $\mathrm{C}$ & $\mathrm{S}$ \\
E10 & $\mathrm{S}$ & $\mathrm{S}$ & $\mathrm{C}$ & $\mathrm{S}$ \\
E11 & $\mathrm{S}$ & $\mathrm{S}$ & $\mathrm{C}$ & $\mathrm{S}$ \\
Güzelyayla & $\mathrm{S}$ & $\mathrm{S}$ & $\mathrm{S}$ & $\mathrm{S}$ \\
Ovacik & $\mathrm{S}$ & $\mathrm{S}$ & $\mathrm{C}$ & $\mathrm{S}$ \\
Cat & $\mathrm{S}$ & $\mathrm{S}$ & $\mathrm{S}$ & $\mathrm{S}$ \\
Hacimahmut & $\mathrm{C}$ & $\mathrm{C}$ & $\mathrm{L}$ & $\mathrm{L}$ \\
Sakaltutan & $\mathrm{N} / \mathrm{A}$ & $\mathrm{N} / \mathrm{A}$ & $\mathrm{N} / \mathrm{A}$ & $\mathrm{N} / \mathrm{A}$ \\
Match $(\%)$ & $21 / 24(87.50)$ & $23 / 24(95.83)$ & $5 / 24(20.83)$ & $23 / 24$ (95.83) \\
\hline & & & & \\
\hline
\end{tabular}

S: Snow, C: cloud, L: Land, and N/A: not applicable

Therefore, the accuracy assessment of the product was evaluated on the basis of daily and 2 day shift analysis. If the grid cell was cloud obscured in the date of ground truth, the images acquired a few days before and a few days after the ground data date were analyzed. It was accepted as matched if a snow covered grid cell existed within 1 or 2 days before or after the date of ground observation.

It is stated by Parajka and Blöschl (2006) that snow depth observations at the climate stations were considered as ground truth for the pixel that was closest to each station. This brings the question on the representativity of the pixel by a point. In these kinds of studies, it is possible to make some kind of averaging to prevent misclassification due to downscaling. Taking the average of eight basic neighboring cells into account may reduce the misclassification errors to some extent due to patchy snow. However, instead of neighboring cells, cells within a certain radius or a data retrieving matrix (Zhou et al., 2005) may be referred for comparison to improve the consistency as well as eliminating mismatch of in situ data location on MODIS snow product. Ground observations were compared to all MODIS grid cells falling within a radius of $1500 \mathrm{~m}$ of each individual observation site. If $50 \%$ or more of all cloud free grid cells within $1500 \mathrm{~m}$ radius were classified as snow by MODIS then the site was considered to be snow covered for comparison purposes.

The confusion matrix table was prepared to indicate the accuracy of the correct classification as snow-snow and no snow-no snow. The percentage ratio of all days (both cloud free and partly cloud covered) were determined. The results were presented with respect to elevation bands in Table 1 and summary of analyses is presented in Table 2. Analyses performed for the period of 2003-2004 for four days between 22-25 March 2004 during which 20 random ground observations site data were collected and processed are given in Table 3. The manual snow course measurements are carried out only if the snow cover exists. Therefore, the consistency analysis could only be available for the days on which snow site measurements were done.

\section{Discussion of results}

\subsection{Comparison of snow maps with ground observations}

While the in situ data represent point measurements, the MODIS values represent an $(500 \mathrm{~m}$ by $500 \mathrm{~m})$ area centered over each site. Therefore, spatial scale differences 
in sampling introduce some amount of error in comparison that cannot be attributed to either in situ or MODIS data. This may become especially important in mountainous regions where the elevation changes drastically. Without in situ albedo sampling at varying scales within the MODIS footprint (pixel), this source of error cannot be eliminated.

For the validation of the MODIS products, comparisons were made at automated stations and snow courses. Some errors were expected due to land cover types, topographical variability, climatologic reasons and the inherent problems faced in the cloud mask used in snow mapping algorithms. The snow cover map obtained through MODIS images on the snow course dates were compared for validation purposes with respect to elevation zones (Table 1) for 2002-2003 winter. On the other hand, Table 2 shows that the consistency percentages increase from $62.24 \%$ to $81.63 \%$ when one or two day before or after for the daily images are taken into account. This can be a partial solution to the cloud obscured problem associated with the use of optical sensors. Otherwise, multi-sensor multi-temporal snow cover area algorithms and microwave images as AMSR-E and SSM/I would be the other alternatives for eliminating the cloud cover problem.

When the contingency table is prepared and analyzed, it is noted that the omission errors (there is snow but missed by the MODIS product) are mostly captured instead commission errors (no snow on the ground but MODIS product determined snow). This observation is true when the cells are fully snow covered (not patchy) and if there is a match in time of observation, otherwise the time shift may cause an underestimation in snow cover with the optical data during the melting stage of the early spring months. The validation analysis captures omission errors but not commission errors. The error matrices for 2002-2003 winter period and 20032004 ablation period are composed of the omission errors. Since the commission errors are missing, the overall accuracy can not be calculated. In order to get the commission errors, higher number of automated stations is required. The SCA algorithm used for MODIS also affects the under and overestimation of snow covered area. Since it does not take into account the topography of the scene, for slopes away from the sun, the reflected radiation received at the satellite will be lower than from horizontal areas and slopes facing towards the sun. This effect is mostly visible in winter. Larger shadows would be expected with small sun angle in mountainous areas. This may result in the estimation of no snow in shadow areas even if the snow cover on the ground is $100 \%$.

Another possibility is that the edges of the snow covered areas and land surfaces may be mapped as cloud. This seems to be one of the problems causing misclassification in the current version of the algorithm. The patchiness and shallow snow depth may be the other major reason of lower accuracies in the comparison.

For the ablation period of March 2004, the accuracy was high as presented in Table 3 within the range of $90-95 \%$.
For the image of 24 March 2004, which is a cloudy day, the matched percentage reduced to $20.83 \%$. As a result, it is concluded that MODIS snow map algorithm correctly captures the snow presence on the ground surface if cloud free image or clear-sky conditions exist.

It is worth mentioning that especially during the period when rapid melting of snowpack starts at low and medium altitudes, high deviation of SCA are expected to occur between simulated models runs and observed satellite products. In that case, not only the number of clear sky images but also the timing of these images are important (Tekeli et al., 2005).

\subsection{Comparison of MODIS daily snow albedo}

In general, MODIS daily snow albedo was found consistent both in magnitude and timing with on-site measurements conducted in Karasu basin shown in Fig. 3. MODIS overestimated snow albedo by $10 \%$ over field observations during the study period. The time difference between MODIS and in-situ data acquisition and the reducing effect of air temperature on snow albedo are considered to be the main reasons for the overestimation. At higher elevations, better agreement was found between MODIS snow albedo and ground observations. The possible reason is that, at the higher elevations, air temperature is lower and, therefore, there may be no localized melting effects on the snowpack to reduce the snow albedo. In addition, continuous snow cover (relatively less patchy snow) at higher altitudes may be another reason that favored the better agreement. Overall, the temporal trends obtained from MODIS during the ablation period were in agreement with ground based observations obtained from the two AWOS. The findings in Tekeli et al. (2006) indicate that MODIS daily snow albedo algorithm gives reasonable results for the area under study.

\subsection{Discussion on hydrologic model application using MODIS products}

The overall aim in this study was to test if satellite snow products can be used in hydrological modeling. This is also emphasized in the text of Parajka and Blöschl (2006). Two days shift analysis may reduce the high cloud cover frequency, however, another solution is the utilization of 8-day product of MODIS. The selection of single image products for the cases when high percentage of clouds are observed restricts the continuous snow depletion curve for the basin. MODIS 8-day snow cover products can be used to minimize the cloud cover and maximize the snow cover extent (Zhou et al., 2005).

The snow covered map information can be used as input for some of the hydrologic model applications, such as Snowmelt Runoff Model (Martinec et al., 1998). In Tekeli et al. (2005), MODIS 8-day snow cover products were used to minimize the cloud cover and to maximize the snow cover extent. So MODIS 8-day products (MOD10A1) were used to 
derive the snow depletion curves for the topographic elevation zones in model simulation runs. The snowmelt runoff hydrograph shape is affected by the elevation bias of the MODIS snow-mapping algorithm, underestimating the area in lower altitudes and overestimating in the higher elevation regions. This difficulty may be overcome by utilizing fractional snow covered area concept using multi-sensor data (SEVIRI, NOAA, MODIS as optical and AMSR-E, SSM/I as microwave). This should be the basic task for future studies; one example is the Satellite Application Facilities in Hydrology (H-SAF) project financed by EUMETSAT that started in September 2005 to which the authors are involved in for algorithm development.

Use of either daily or 8-day snow covered maps may lead to a further study which would be the sensitivity analysis of MODIS maps on model runoff simulation studies. Also it would be a good idea about the timing and number of images to be used in optimum manner. In another study, Akyürek and Şorman (2002) estimated the snow covered area by supervised classification of NOAA-AVHRR data in order to obtain the snow depletion curves as an input parameter for a snow runoff model for the same basin. The effects of aspect and slope on the snow depletion curves for different elevation zones were analyzed. It is well known that solar illumination and shadowing have great effect on snowmelt, creating a north-south direction difference. Snow on the northwest slopes melted earlier compared to southeast slopes due to the steep slopes and prevailing wind direction. These results show that besides the elevation and land use which are stated as the main factors that may influence the MODIS classification accuracy, aspect, slope and prevailing wind direction as well as speed may also have an indirect effect on the classification accuracy.

It is hoped that these kind of studies would be a pioneer for the countries where crucial water resources especially from snowmelt must be shared and used efficiently among the beneficiaries.

Edited by: N. Romano

\section{References}

Akyürek, Z. and Şorman, A. Ü.: Monitoring snow covered areas using NOAA-AVHRR data in the eastern part of Turkey, Hydrol. Sci. J., 47(2), 243-252, 2002.

Bitner, D., Carroll, T., Cline, D., and Romanov, P.: An assessment of the differences between three satellite snow cover mapping techniques, Hydrol. Processes, 16, 3723-3733, 2002.

Hall, D. K., Riggs, G. A., and Salomonson, V. V.: Algorithm theoretical basis document (ATBD) for the MODIS snow and sea ice mapping algorithms, available at: http://modis.gsfc.nasa.gov/ data/atbd/atbd_mod10.pdf, 2001.
Hall, D. K., Riggs, G. A., Salomonson, V. V., DiGirolamo, N. E., and Bayr, K. J.: MODIS snow cover products, Rem. Sens. Environ., 83, 181-194, 2002.

Key, J. R., Collins, J. B., Fowler, C., and Stone, R. S.: High altitude surface temperature estimates from thermal satellite data, Rem. Sens. Environ., 61, 302-309, 1997.

Klein, A. G., Hall, D. K., and Nolin, A. W.: Development of a prototype snow albedo algorithm for MODIS, in: Proceedings of 57th Annual Eastern Snow Conference, Syracuse, NY, 143-157, 17-19 May 2000.

Klein, A. G. and Stroeve, J.: Development and validation of a snow albedo algorithm for the MODIS instrument, Ann. Glaciol., 34, 45-52, 2002.

Klein, A. G. and Barnett, A. C.: Validation of daily MODIS snow cover maps of the upper Rio Grande basin for 2000-2001 snow year, Rem. Sens. Environ., 86, 162-176, 2003.

Klein, A. G.: Determination of broad band albedos of partially snow covered sites for validation of MODIS snow albedo retrievals, in: Proceedings of the 60th Eastern Snow Conference, Sherbrooke, Canada, 23-35, 4-6 June 2003.

Liang, S., Strahler, A. H., and Walthall, C. W.: Retrieval of land surface albedo from satellite observations, J. Appl. Meteorol., 38(6), 712-725, 1999.

Martinec, J., Rango, A., and Roberts, R.: SRM User's Manual, Geographico Bernensia P29, Department of Geography, University of Berne, Switzerland, 1998.

Maurer, E. P., Rhoads, J. D., Dubayah, R. O., and Lettenmaier, D. P.: Evaluation of the snow covered area data product from MODIS, Hydrol. Processes, 17, 59-71, 2003.

Parajka, J. and Blösch, G.: Validation of MODIS snow cover images over Austria, Hydrol. Earth Syst. Sci., 10, 679-689, 2006, http://www.hydrol-earth-syst-sci.net/10/679/2006/.

Salomonson, V. V. and Appel, I. :Development of the Aqua MODIS NDSI fractional snow cover algorithm and validation results, IEEE Transact. Geosci. Rem. Sens., 44, 7, 1747-1756, 2006.

Salomonson, Y. Y. and Appel, I.: Estimating fractional snow cover from MODIS using the normalized difference snow index, Rem. Sens. Environ., 89(3), 351-360, 2004.

Simic, A., Fernandes, R., Brown, R., Romanov, P., and Park, W.: Validation of vegetation, MODIS and GOES+SSM/I snow-cover products over Canada based on surface snow depth observations, Hydrol. Processes, 18, 1089-1104, 2004.

Tekeli, E., Akyurek, Z., Şorman, A. A., Şensoy, A., and Şorman, A. Ü.: Using MODIS Snow Cover Maps in Modeling Snowmelt Runoff Process in the Eastern Part of Turkey, Rem. Sens. Environ., 97, 216-230, 2005.

Tekeli, E., Şensoy, A., Şorman, A. A., Akyurek, Z., and Şorman, A. Ü.: Accuracy assessment of MODIS daily snow albedo retrievals with in situ measurements in Karasu basin, Turkey, Hydrol. Processes, 20(4), 705-721, 2006.

Zhou, X., Xie, H., and Hendrickx, J. M. H.: Statistical evaluation of remotely sensed snow-cover products with constraints from streamflow and SNOTEL measurements, Rem. Sens. Environ., 94, 214-231, 2005. 